Plantae Scientia - An International Research Journal in Botany Publishing Bimonthly Open Access Journal

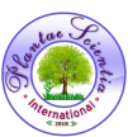

Plantae Scientia : Volume 02, Issue 03, September 2019

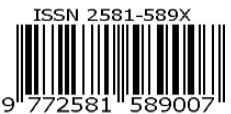

RESEARCH ARTICLE

\title{
Nutraceutical Investigations of Commelina diffusa Burm. f. Leaves - A Popular Wild Vegetable
}

\author{
Sanjay A. Kamble \\ Department of Botany, Vinayakrao Patil College Vaijapur Pin -423701 Dist. Aurangabad (M.S) India \\ Corresponding Author: drsanjaykamble279@gmail.com
}

\section{Manuscript Details}

Manuscript Submitted : 24/08/2019

Manuscript Revised : :28/08/2019

Manuscript Accepted : :13/09/2019

Manuscript Published : 15/09/2019

\section{Available On}

\section{https://plantaescientia.website/ojs}

\section{Cite This Article As}

Kamble S A, (2019). Nutraceutical investigations of Commelina diffusa Burm $\mathrm{f}$ leaves - A popular wild vegetable. Pla. Sci. 2019; Vol. 02 Iss. 03: 36-39. DOI:https://doi.org/10.32439/ps.v2i3.34-39

\section{Copyright}

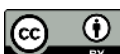

(c) The Author (s). 2019. Open Access This article is distributed under the terms of the Creative Commons Attribution 4.0 International License http://creativecommons.org/licenses/by/4.0/

$\underline{\text { Indexed In }}$

Crossref, Index Copernicus International (ICI), Directory of Research Journal Indexing (DRJI), Scientific Indexing Services (SIS), CiteFactor

\section{ABSTRACT}

Aqueous leaf extracts of Commelina diffusa Burm $\mathrm{f}$. was evaluated for food value. The results show that the proximate and vitamin compositions of Commelina diffusa Burm $\mathrm{f}$. included mainly Moisture (83.36\%), Carbohydrate (6.32\%), Vitamin C (44.80 mg/100g dry weight), Vitamin B3 (63.18mg/100g) and Vitamin B2 (8.30 mg/100g) respectively. The mineral contents of the defatted leaf extracts were found to be $\mathrm{Na}(69.32 \mathrm{mg} / \mathrm{l} 100 \mathrm{~g}), \mathrm{Ca}(232.00 \mathrm{mg} / \mathrm{l00g})$ and $\mathrm{Mg}$ $(84.28 \mathrm{mg} / \mathrm{l00} \mathrm{g})$. The proximate, vitamin and mineral compositions obtained suggest that the leaves, as cheap sources of vitamins C, B3 and B2, as well as other macro-and micronutrients, can be incorporated into human and animal diet to meet their recommended daily allowances. The content of flavonoids and vitamin $C$ in the leaf extracts also suggests possible anti-oxidant effects of these leafy vegetables.

Keywords: Commelina diffusa Burm. f, Proximate Vitamins and Minerals, Anti-oxidants.

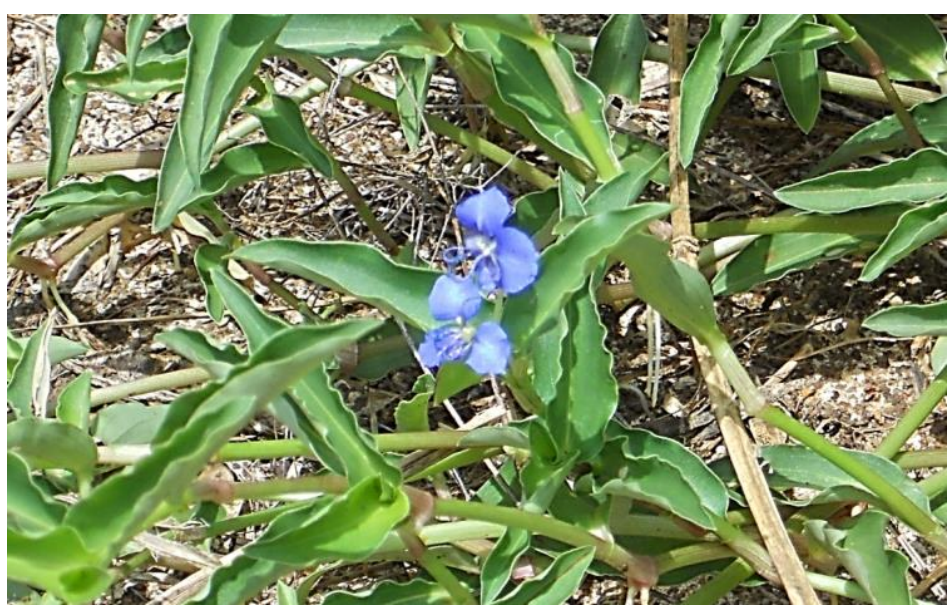

Fig.1 : Commelina diffusa Burm f. (Commelinaceae) 


\section{INTRODUCTION}

In India vegetarian peoples are depend upon vegetables. More than sixty per cent of population is a vegetarian. They are consuming vegetable along with many recipes. The vegetable is basically any part of a plant, be it leaves, roots, seeds or fruits that can be eaten. This food of plant origin contains many bioactive compounds and thus serves as an important source of minerals, vitamins and certain hormone precursors in addition to protein and energy sources (Cho et al., 2004). These notwithstanding, leafy vegetables have continued to provide populations with limited access to meat or fish, a rich source of proteins and micronutrients essential for pregnant and lactating mothers, as well as young and growing children (Penny et al., 2002). Studies have shown that vegetarians are less susceptible to diseases, live longer, healthier and more productive lives with stronger immunity (Akindahunsi \& Salawu, 2005). However, there has been a growing reduction in the consumption of vegetables with each passing decade (Aranceta, 2004).

Commelina diffusa Burm. $f$ (Figure 1 ) is wild species of vegetable. It belongs to family Commelinaceae. Their habit is annual as well as perennial, height of plant up to 0.80 meter. They are not cultivated but appear on barren lands, in fields, at roadsides. The leaves are cooked and used as vegetable food at many places in India. They are of medicinal importance. The leaves are diuretic and febrifuge. The crushed leaves and stems are used as remedy for irregular menstruation. The leaves are widely used for politicking sores. The stem mucilage is useful on chronic wounds. In India, it is said to be beneficial in the treatment of leprosy (Keary \& Hepper, 1985). However, the plant is relatively under-utilized and in most cases neglected. It is seen as weeds in farms (Keary \& Hepper, 1985). The leaves are cooked and eaten as vegetable. Domestic livestock also grazes the plant especially during famine. It has an advantage of providing significant amounts of animals' water requirement.

The neglecting of such type of vegetables coupled to the growing reduction in consumption of vegetables prompted this Study. The Nutritional compositions of Commelina diffusa will throw light on its food value; through this study will increase interest in common peoples to use it as edible vegetable? It is still doubtful as the plant traditionally not been used as edible vegetable due to lack of knowledge of its nutritive value.

\section{MATERIAL AND METHODS}

Collection and preparation of plant materials: Whole plant of Commelina diffusa was collected from a barren land of college campus at V.P. College Vaijapur Dist. Aurangabad (M.S.) apparently, healthy leaves of plants were removed from plant stalk, rinsed in clean water and dried to a constant weight at $60^{\circ} \mathrm{C}$ using laboratory oven. The dried plant samples were ground to fine powder with an electric grinder, packaged in glass jars and stored at $4^{\circ}$ until analysis.

\section{Proximate Analysis}

The proximate analysis of the leaf extract for moisture, ash and carbohydrate contents were determined as described by AOAC (1990). Crude protein, fibre and fat contents were determined using the methods described by Pearson (1976). Total ash content was determined by furnace incarnation using the method of James (1995). All determinations were done in triplicates

\section{Analysis of Vitamins and Minerals}

The vitamins $\mathrm{C}$ and $\mathrm{B}$ contents of the vegetables were determined using High-Performance Liquid Chromatography (HPLC). Iodine and iron contents were determined by spectrophotometer. The other minerals, sodium, potassium, calcium, magnesium, manganese, copper. Zinc were estimated by using an atomic absorption spectrophotometer.

Table 1: Proximate nutritive Compositions (\%) of Commelina diffusa Burmf

\begin{tabular}{|clc|}
\hline Sr. No. & Composition & \% Content \\
\hline 01 & Moisture & 83.38 \\
\hline 02 & Ash & 01.07 \\
\hline 03 & Protein & 01.69 \\
\hline 04 & Fat & 01.44 \\
\hline 05 & Carbohydrate & 06.32 \\
\hline 06 & Fiber & 01.50 \\
\hline
\end{tabular}

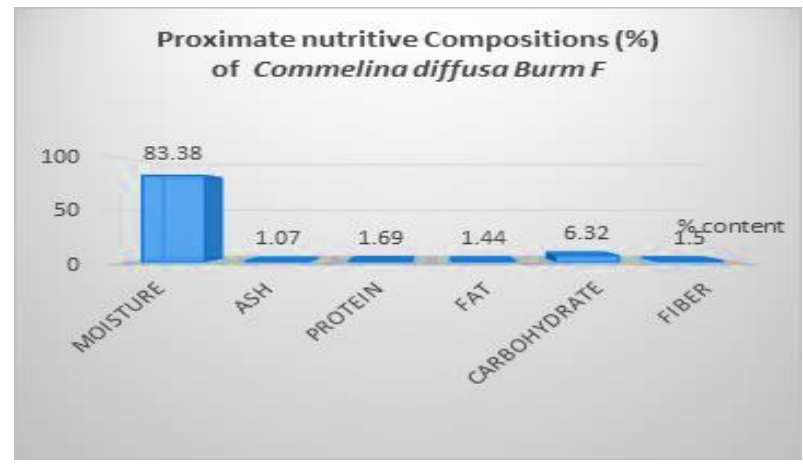

Graph 1: Proximate nutritive Compositions (\%) of Commelina diffusa Burm. F.

Table 2: Mineral Compositions (mg/100gm) Commelina diffusa Burm. F.

\begin{tabular}{|rll|}
\hline Sr. No. & Composition & Content in $\mathrm{mg}$ \\
\hline 01 & Sodium & 69.32 \\
\hline $\mathbf{0 2}$ & Potassium & 0.78 \\
\hline $\mathbf{0 3}$ & Calcium & 232.00 \\
\hline $\mathbf{0 4}$ & Iron & 0.017 \\
\hline $\mathbf{0 5}$ & Magnesium & 84.28 \\
\hline $\mathbf{0 6}$ & Copper & 0.14 \\
\hline
\end{tabular}




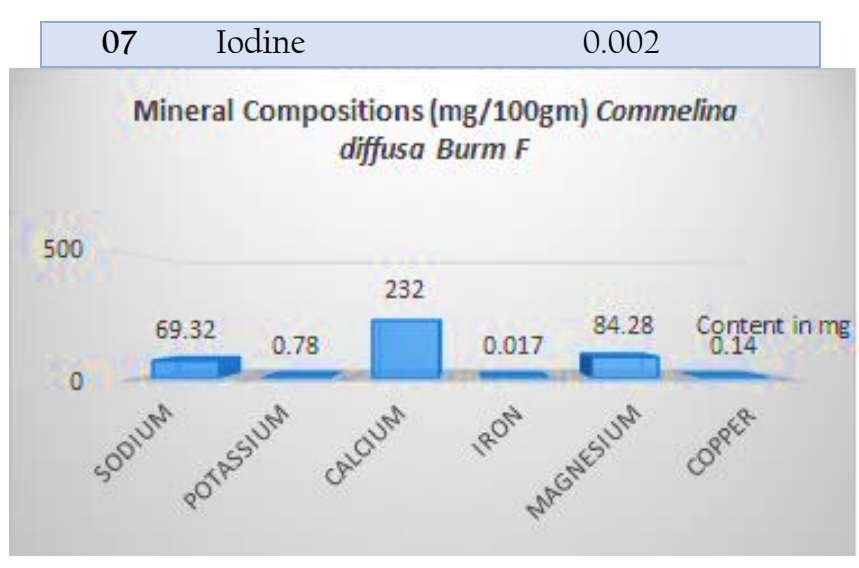

Graph 2: Mineral Compositions (mg/100gm) Commelina diffusa Burm. F.

Table 3: Vitamin Compositions (mg/100gm) of Commelina diffusa Burmf.

\begin{tabular}{|clc|}
\hline Sr. No. & Composition & Content in mg \\
\hline 01 & Vitamin B1 & 13.21 \\
\hline $\mathbf{0 2}$ & Vitamin B2 & 8.30 \\
\hline $\mathbf{0 3}$ & VitaminB3 & 63.18 \\
\hline $\mathbf{0 4}$ & VitaminB6 & 13.21 \\
\hline $\mathbf{0 5}$ & Vitamin C & 44.80 \\
\hline
\end{tabular}

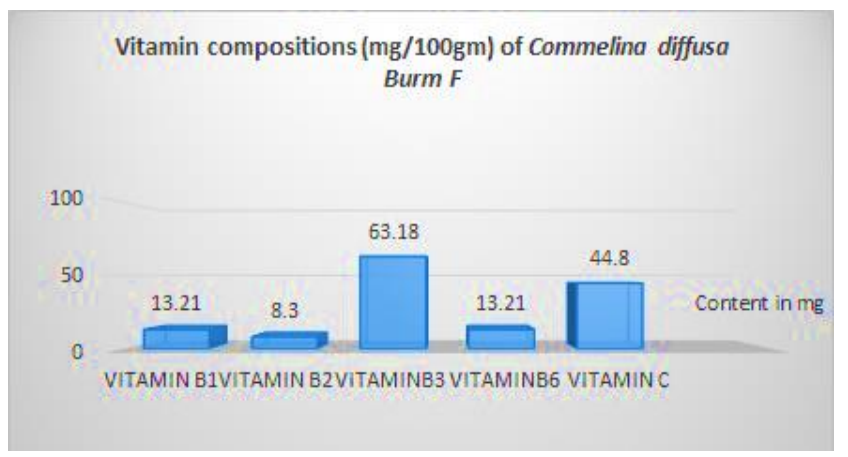

Graph 3: Vitamin Compositions (mg/100gm) of Commelina diffusa Burm. $f$.

\section{RESULTS AND DISCUSSION}

It is observed that at the concentration of much chemical composition in edible vegetables, they are usually non-toxic. Furthermore, steaming or boiling reduces their levels in plant extracts (Piorreck et al., 1984). These vegetables also contain flavonoids, which are phenolic compounds that serve as flavouring ingredients of spices and vegetables (Enwere, 1998). They have been found to have anti-oxidation effects in animals.

The proximate compositions of Commelina diffusa given in Table 1 the values showed that the vegetables contain high percentage composition of moisture (83.38\%). Their contents of fat $(1.44 \%)$, protein $(1.69 \%)$ and carbohydrate (6.32\%) were low when compared to the values of $25.35 \%$ and $29.50 \%$ reported for a neglected leafy vegetable, Amaranthus hybridus (Nwaogu et al., 2006). However, the good distribution of nutrients in the vegetables may explain why domestic animals graze them (Keary \& Hepper, 1985).

Some of the vitamin compositions of the vegetables are given in Table 3. Commelina diffusa Burm. f. found to also contain the vitamins Bl (13.21 mg/100mg),C (44.80 mg/100mg), Vitamin B3 $(63.18 \mathrm{mg} / 100 \mathrm{mg}), B 6(13.21 \mathrm{mg} / 100 \mathrm{mg})$ and Vitamin B2 $(8.30 \mathrm{mg} / 100 \mathrm{mg}$ ) of the vitamins. Vitamin B3 (nicotinamide) helps in the breakdown of blood sugar, dilation of blood vessels and thus increases blood flow. Its daily-recommended allowance is $20 \mathrm{mg}$ /day (Trumbo et al., 2004), thus a judicious intake of these vegetables will provide adequately the needed quantity per day. The vegetables also contain vitamin C (ascorbate), the deficiency of which causes scurvy in humans. Vitamin C facilitates wound healing, production of collagen, formation of red blood cells and boosts immune system. The recommended daily allowance of vitamin $C$ is $75 \mathrm{mg} /$ day. Commelina diffusa Burm. f. has higher content of vitamin B2 (riboflavin) the vitamin is essential for energy production and in its co-enzyme forms (FMN and FAD), it serves as hydrogen transport systems (Mayes et al., 2000). The results of the present study show that the vegetables are of high nutritional value and may help essentially in the control of physiological oxidative stress given their high content of vitamin C and flavonoids (Wright, 2005). Some of the mineral constituents of the defatted leaves are given in Table 2. The sodium, calcium and magnesium contents of Commelina diffusa Burm f. were high at 69.32, 232.00, and $84.28 \mathrm{mg} / 100 \mathrm{~g}$, Potassium $0.78 \mathrm{mg} / 100 \mathrm{~g}$, Copper $0.14 \mathrm{mg} / 100 \mathrm{~g}$ and Iodine $0.002 \mathrm{mg} / 100 \mathrm{~g}$ of dry weight. The vegetables have adequate concentrations of sodium and calcium, equivalent concentrations of magnesium, but with low contents of potassium and iron in comparison with those reported in $A$. hybridus leaf extract (Nwaogu et al., 2006).

\section{CONCLUSION}

The study has revealed that leaves of Commelina Diffusa are potential sources of nutrients and some essential macro and micronutrients needed by man. The importance of these nutrients cannot be overemphasized for effective and proper metabolism as well as the maintenance of good physiological state in man and animals. The plant Commelina diffusa Burm. f. can replace many vegetables to use for its consumption. No doubt due to its estimated nutritive value, it is table vegetable in future.

\section{ACKNOWLEDGEMENTS}

The author is thankful to Dr. Panchal U V. Principal Vinayakrao Patil Vaijapur for his support providing laboratory facility. The author is also thankful to Dr. G. R. Hanwate, Dr. Vasantrao Naik Marathwada Agriculture 
University Parbhani (MS) for his constant support in the estimation.

\section{REFERENCES}

Akindahunsi, A.A. and Salawu, S.O., (2005). Phytochemical screening and nutrient-antinutrient composition of selected tropical green leafy vegetables. African Journal of Biotechnology. 4: 497-501.

AOAC, (1990). Official methods of analysis. Association of official analytical chemists. 15th ed. Washington D.C., pp: 12-13.

Aranceta, J., (2004). Fruits and vegetables. Arch. Latinoam Nutr., 2: 65-71

Cho, E., J. Seddom, B. Ronser, W. Willet and S. Hankison, (2004). Prospective study of intake of fruits, vegetables, vitamins and carotenoids and related musculopathy. Arch. Opthal., 122: 883-892.

Enwere, N.J., (1998). Foods of plant origin. Enugu, Nsukka Afroorbis Publications, pp: 736-741. James, S.C., (1995). The analytical Chemistry of foods. London, Blackie Academy and professional Publication, pp: 100-112.

Keary, R.W. and F.N. Hepper, (1985). The useful plants of West Tropical Africa. Britain, White Friars Press Limited, pp: 429-430.

Mayes, P.A., (2000). Harper's Biochemistry. 25th Ed. New York, McGrawHill, pp: 627-641.

Monsen, E.R., (2000). Dietary reference intake for antioxidant nutrients. J. Am. Diet Asso.100: 637-640.

Nwaogu, L.A., C.O. Ujowundu and A.I. Mgbemena, (2006). Studies on the nutritional and phytochemical composition of Amaranthus hybridus Leaves. Bio Res., 4: 28-31.

Pearson, D., (1976). The chemical analysis of foods.7th Ed. London, Churchill Livingstone pp: 3-4.

Penny, M.K., D.H. Karr, B. Andrea, M.C. Stacie, E.B. Amy, F.H. Kristen, E.G. Amy and D.E. Terry, (2002). Bioactive compounds in foods: their role in the prevention of cardiovascular disease and cancer. Experta Medica, 10: 210-211

Piorreck, M., K. Baasch and P. Pohl, (1984). Biomass production, total protein, chlorophylls, lipids and fatty acids of freshwater greens and bluegreen algae under deficient nitrogen regime. Phytochemistry, 23: 207-216

Trumbo, P., A.A. Yates, S.A. Schlicker and M.I. Poss, (2004). Dietary reference intakes. J. Am. D. Diet assol01:294-301

Wright, K., (2005). Healing foods. Poland, Geddes and composition of selected tropical green leafy vegetables, AJB., 4: 497-501.

Wright. K. (2005). Healing foods. Poland. Geddes and Grosset. pp 8-20.

@ 2019| Published by Plantae Scientia 